\title{
10 Trade reform, macroeconomic policy and sectoral labour movement in China
}

\section{Jennifer Chang and Rod Tyers}

Although the Chinese economy continues to grow rapidly, since the Asian financial crisis of the late 1990s there is evidence of a slowdown, most prominently in per capita rural income growth. One explanation for this is that the relocation of labour from agriculture to manufacturing and services, essential in any growing developing economy, has been retarded. This could be due to policy disincentives designed to control urban congestion, such as the household registration or hukou system (lanchovichina and Martin 2002a) or information asymmetries and transaction/infrastructural costs (Sicular and Zhao 2002). A further hypothesis attributes comparatively poor performance in China's rural sector to economic reforms; in particular, to trade reform commitments in the leadup to and associated with WTO accession (Anderson et al. 2002).

It is the central hypothesis of this chapter that this comparative decline in rural performance is due, at least in part, to a combination of China's adherence to its de facto fixed exchange rate regime and to shocks that have tended to depreciate its real exchange rate. Most significant amongst these shocks was the surge of (largely illegal) outflows on the capital account

First published in Garnaut, R. and Song, L. (eds), 2003. China: New Engine of World Growth, Asia Pacific Press, Canberra:231-75. 
and the associated private investment slowdown during the Asian financial crisis (Yang and Tyers 2001). Since then, however, numerous trade reforms have been implemented, all of which have tended to encourage Chinese consumption to shift toward foreign goods, so reducing home relative to pre tariff foreign goods prices and hence further depreciating the real exchange rate (Tyers and Rees Chapter 9). By definition, a real depreciation must be accompanied either by a nominal depreciation, a domestic deflation, or a combination of both. The de facto peg to the US dollar has therefore necessitated China's deflation. When prices are falling there is downward pressure on wages. Even if wages fall only slightly more slowly than prices, however, other things being equal, employment growth in the wage sectors of the economy can be expected to decline. ${ }^{1}$ In the Chinese case this appears as high real wage growth in the modern sector but reduced labour demand growth there and hence a 'bottling up' of workers in the rural sector and reduced rural income per capita.

The relevance of this story to China's comparatively poor recent per capita rural income growth performance is examined here using short and long-run comparative static analysis. The shocks considered are China's WTO accession commitments and the model used is that described in Tyers and Rees (Chapter 9). This model is a development of the model introduced by Yang and Tyers (2000). It is a multi-sector, multi-country comparative static macro model, the microeconomic components of which have their origins in GTAP. ${ }^{2}$ All countries have open capital accounts and forward-looking investor behaviour is represented in the short run via expectations formed from long-run simulations. The focus here, however, is on labour relocation and the short run consequences of trade reform shocks for the uptake of labour in the manufacturing and services sectors. ${ }^{3}$ We examine the pace of such labour relocation historically and compare this with simulated changes in labour demand following the WTO accession.

We observe a reversal in the rate of relocation of workers from agriculture to manufacturing after 1998 and a glut of workers in the rural sector (Dolven 2003). Our simulations suggest that the retarding effect of the commonly cited system of internal migration restrictions, known as the hukou or household registration system (HRS), has been enhanced by China's broader macroeconomic policy regime. Indeed, the exchange rate 
regime, combined with capital controls, appears to have restricted the flow of workers into manufacturing and services by at least 1 per cent per year and into services by at least 2 per cent per year.

\section{Urban-rural inequality and worker relocation in China}

The pace of rural per capita income growth depends on the rate at which surplus labour is generated by agricultural change and the corresponding rate at which workers are accommodated in the manufacturing and services sectors. It is a common view that the economic reform of the early 1980s, which brought de-collectivisation and the household responsibility system, along with associated increases in agricultural labour productivity, created a substantial rural labour surplus. ${ }^{4}$ Moreover, prior to that reform, wages were not market-determined and there is evidence of considerable underemployment. This was due, in part, to the seasonal nature of agricultural activity, which meant that many workers were left idle in the off-peak parts of the agricultural cycle, yet unable to take full employment elsewhere (Banister and Taylor 1989).

An exacerbating factor on the supply side in the Chinese case was rapid rural population growth in the pre reform period. Even though the rate of rural population growth slowed in the 1970s and 1980s, the growth of the rural labour supply continued strongly due to the aftermath of the 'baby boom' periods of the 1950s and 1960s. ${ }^{5}$ On the demand side, China's pre reform economic strategy promoted relatively capital-intensive heavy industries. These two effects tended to raise underemployment in the rural sector in the post reform period, where, although rural communes were disbanded, all workers were still technically employed. ${ }^{6}$ The post reform period therefore carried considerable potential for worker relocation from agriculture into other sectors. The subsequent volume of internal migration would depend, then, on economic incentives in the form of urban-rural income inequality and on both policy-induced and natural barriers to migration. 


\section{Urban-rural inequality in China}

Income inequality in China exists between urban and rural residents as well as within urban and rural areas. It also has a strong regional pattern, particularly between inland and coastal provinces. Of overall income inequality, Lozada (2002) estimates that $75-80$ per cent is due to the urban-rural divide. Official estimates of the trends of rural and urban household incomes are displayed in Figure 10.1. These indicate a general upward trend in income in both areas while urban income experienced comparatively sharp increases in the 1990s. The corresponding proportional difference between urban and rural household incomes is plotted in Figure 10.2. The comparatively rapid growth of rural incomes in the early $1980 \mathrm{~s}$, and the associated decline in urban-rural inequality, coincided with the major reforms of that period that first impacted on the rural sector. Since then, however, urban incomes have growth more rapidly, most prominently in the early to mid 1990s leading up to the Asian crisis in 1997-98, and in the post crisis period.

Internal migration

If there were no costs or barriers to internal migration, workers would be expected to respond to the widening income gap between rural and urban areas by migrating until wages were equalised. Indeed, rural labour markets that facilitate this relocation of workers have been essential to economic growth in the more advanced countries (Burgess and Mawson 2003). Although the estimated number of Chinese internal migrants has grown (100 million since the 1980s) these relocations have been insufficient to stem the growing inequality (Dolven 2003). Some of this apparent growth in inequality is due to a rise in skilled employment in urban areas. A more controversial portion is due to reduced urban labour demand associated with real wage growth and to official migration barriers. Together, they appear to have left an expanding labour supply 'bottled up' in the rural sector. The key official barrier has been the HRS.

Introduced in major cities in 1951 and extended to rural areas in 1955, the HRS was intended to deal with the escalating urban influxes of rural migrants at the time of the Great Famine of 1959-61 (Chan and Zhang 1999). 
The associated food shortages continued into the 1970s, only ending in the 1980s (Zhao 2000). Each citizen is required to register in their place of regular residence, often their birthplace. Moving from rural to urban areas requires a complex and costly application for a transfer to a local hukou. Prior to the reform in the 1980s, this was a huge barrier, as without a proper hukou one would not qualify for a government job assignment. Workers who ignored this requirement were denied social security benefits such as housing and other necessities, even food.

Decollectivisation in rural areas allowed income inequality to soften a little and non-farm rural industries to develop. This, and the household responsibility system that accompanied it, had the effect of increasing productivity in the agricultural sector. Thus, while rural incomes grew, so also did the proportion of workers considered redundant. ${ }^{7}$ The government began rewarding collective farms and cooperatives for production rather than labour employed, so excess workers could be free to look for other jobs (Seeborg, Jin and Zhu 2000). The marketisation of food also meant that migrants were no longer restrained entirely by the need to obtain a local hukou to survive. Combined with the development of special economic zones and the increase in urban private and informal sectors, the cities were on a path of rapid development with growing demand for labour. Yet the HRS created ambiguous incentives for migrants. On the one hand, it constrained people with access to land from migrating, since each was now responsible for their own land, which most saw as a form of social security. On the other hand, individuals with little or no access to land or who had specialised in what were to become low productivity rural activities were now less constrained.

Through the 1980s and 1990s the HRS was gradually weakened by policy reforms and less stringent enforcement. Previously prohibited 'spontaneous' migration to jobs in urban centres was tacitly facilitated and tolerated, conditionally opening urban residency to rural workers and relaxing some of the strict controls. There has therefore been an increase in temporary urban migrants: workers going to cities and towns without official residential status, known as the 'floating population'. Figures from the late 1980s indicate that transients made up over one-fifth of the population of such major cities as Beijing, Shanghai, and Guangzhou (Canadian Immigration and Refugee Board 2002). Many official restrictions remained, however, including the 
link between hukou status and welfare eligibility, the denial of education for migrant children, and state job availability. In 1995, to re-assert control over internal migration, Zhao (2000) notes that tighter controls were imposed over the legality of urban residency and housing subsidies. ${ }^{8}$

As part of China's urbanisation strategy for the 10th Five-Year plan, Central Party Document Number 11 of November 2000 allows a person and his or her immediate family to obtain urban hukous if he or she has fixed accommodation and stable work (in a job for more than one year) in the urban area. Urban hukou was also offered to those who purchased a local commercial housing unit (to attract outside investment) and to holders of graduate degrees (attracting professionals). The focus of these reforms was still mainly on small towns and small cities, however. Nonetheless, according to China's Committee to Restructure the Economy (SCORES), during 2001 about 600,000 rural residents acquired urban hukou in these small urban centres. More recently still, a State Council directive indicated that rural migrants have a legal right to work in cities. It prohibits job discrimination based on residency and orders that urban residency documents are to be provided to any workers who find employment. A further recent directive indicates that businesses should stop delaying wage payments to workers. This is a significant improvement for migrant workers as they often find that they are taken advantage of due to their uncertain legal status.

Official barriers to migration therefore appear to have had an ever diminishing effect and the least effect in the period since the Asian crisis of 1997. Other things equal, then, we would expect an acceleration in the relocation of workers into jobs in the modern sector in that period. This is not what the evidence suggests, however.

\section{Sectoral relocation of workers}

The trends in employment by major sector are indicated in Figure 10.3. The early 1990s was a period of rapid industrial expansion during which workers relocated from the rural sector to the industrial and services sectors. Significantly, while the expected long term rise in the share of services in total employment is borne out, industrial employment fell substantially during the Asian crisis period and failed to expand thereafter. Indeed, the farming and forestry sector shows annual declines in employment 
that peaked in 1993 and continued until 1996. In this period the Chinese economy grew at its greatest historical rates. During the Asian crisis and in the period thereafter, however, declines in the growth rates of activity in manufacturing and services appear to have driven workers back to the rural sector. In the post crisis period this backflow appears to have continued.

\section{Performance since the Asian crisis}

Good weather and improved farming incentives brought a resurgence of the rural economy in 1995 and the reform of state-owned industrial enterprises (SOEs) was accelerated, precipitating substantial lay-offs (Meng 1998). These changes changed saving incentives, leading to a sudden increase in the private saving rate (Yang and Tyers 2000, 2001). The contractionary effects of these internal shocks were worsened by the arrival of the Asian financial crisis in 1997, which saw the mostly illegal flight of a substantial part of China's additional private savings, leading to a fall in private investment. At the same time, the slowdowns and currency depreciations in other Asian economies made their exports relatively competitive, so that the dollar value of China's exports grew more slowly than in 1990-96 (Yang 1998).

Our macroeconomic policy story begins with the crisis and China's reaction to it. The shocks of that period, the rise in the domestic saving rate, the increased outflow on the capital account, and the adverse change in the terms of trade depreciated the real exchange rate. This effect can be seen from the following definition of the real bilateral exchange rate, for region $i$ with region $j$, as the common currency ratio of the price of a basket of region i's goods and the price of a corresponding basket of region $j$ 's goods:

$$
e_{i j}^{R}=E_{i j}\left(\frac{P_{i}^{Y}}{P_{j}^{Y}}\right)=\frac{P_{i}^{Y}}{\left(\frac{P_{j}^{Y}}{E_{i j}}\right)},
$$

where $E_{i j}$ is $i$ 's nominal exchange rate with $j$, measured as foreign currency units per local unit and the price index used is the GDP price, $P^{r}$. 9 The real exchange rate depreciates when the price of the basket of home goods falls relative to the corresponding basket of foreign goods. The real 
depreciation in the crisis, combined with the fixed nominal exchange rate of the period, necessitated a monetary policy sufficiently restrictive to bring about a decline in the home price level relative to that in the US-a deflation. This was the first in a series of deflations in the crisis and post crisis periods.

Shocks that cause real depreciations also include the other elements of China's domestic reform program. By raising productivity, these reduce domestic costs relative to foreign costs and hence they tend to reduce relative domestic prices. Similarly, trade reforms divert domestic demand away from home produced goods toward imports and so they also tend to reduce the prices of domestic goods relative to the import prices of foreign goods. In the period 1997-2001 China embarked on substantial trade liberalisation, a major part of which included the introduction of a duty drawback system on the imported inputs of export firms (Tyers and Rees, Chapter 9). Real depreciations due to such shocks are robust to China's macroeconomic policy regime. But it is that regime which distributes the nominal effects of the real depreciations between falls in the home price level, or deflation, on the one hand and depreciation of the nominal exchange rate on the other.

The declines in China's official measures of the domestic price are indicated in Table A10.1. ${ }^{10}$ Other things held equal, such deflations are contractionary. This is because, even in the most flexible of industries, wage rates are renegotiated more rarely than product prices are adjusted. Lags in wage adjustment mean that deflation applies a profit squeeze that retards both employment growth and investment in the private sector. Consistent with this, real wage growth in China's modern sector has been extraordinarily high since 1996, as Figure 10.5 shows, suggesting some deterrence of labour demand growth and hence of growth in this sector. Weaker overall performance of the Chinese economy is indicated by its official GDP growth rates (Figure 10.4). These bottomed out in the crisis period at between seven and 8 per cent per year, and have not recovered since.

Since 2001 China has embarked on a still more dramatic set of trade reforms as part of its commitments associated with WTO accession. By themselves, these reforms will cause further real depreciations. Should there be no change in macroeconomic policy, growth and the relocation of workers into China's modern sector will continue to be retarded by 
deflation. In the remainder of the paper we investigate the relationship between growth, labour relocation and macroeconomic policies in the aftermath of the WTO accession reforms.

\section{Modeling the effects of China's trade policy reforms}

Here we simulate the short-run effects of trade reforms in China while accounting for the implications of services trade commitments as well as productivity changes associated with these reforms. As in Tyers and Rees (Chapter 9) and lanchovichina and Martin (2002a), we make allowance for idiosyncratic trade policies, such as the duty drawbacks on imports used in the manufacture of exported goods. And, as befits a short-run analysis, we also allow for labour market rigidity and associated departures from full employment.

Following Yang and Tyers (2000), we use a comparative static global macroeconomic model, within which the microeconomic (supply) side is adapted from GTAP,11 a multi-region comparative static model in real variables with price-taking households and all industries comprising identical competitive firms. To this microeconomic base are added independent representations of governments' fiscal regimes, with both direct and indirect taxation, as well as separate assets in each region (currency and bonds) and monetary policies with a range of alternative targets. The details of the model are described in Tyers and Rees (Chapter 9).

\section{Simulated effects of accession policy reforms}

A long-run outlook is required in order that the expectations of investors can be formulated for short-run analysis-investors are assumed to take changes in long-run returns on installed capital into account in determining short run changes in their investment behaviour. Long-run results are also of interest in their own right.

The key elements of the long-run closure are as follows

- there are no nominal rigidities (no rigidity of nominal wages)

- production and consumption elasticities of substitution are chosen at 'standard' levels to reflect the additional time for adjustment in the long-run over the short run (Tyers and Yang 2001) 
- physical capital is no longer sector-specific; it redistributes across sectors to equalise rates of return

- capital controls are ignored, and

- in China, irrespective of short-run fiscal policy assumptions, in the long-run any loss of government revenue associated with tariff changes is assumed to not be made up via direct (income) taxes, with the result that the fiscal deficit expands.

The key point of difference between our long-run analysis and that of Tyers and Rees (Chapter 9) is that we represent the effects of trade reforms on productivity. There is a substantial literature identifying this association (Chand et al. 1998, Chand 1999 and Stoeckel et al. 1999). These studies use Australian data on the long-run effects of trade reforms to identify elasticities of total factor productivity to protection level by industry. We applied these elasticities to China's intended reforms, albeit with discounts for China's lower starting protection levels in some industries and adjustments to account for services sector reforms (Dee and Hanslow 2000, Verikios and Zhang 2001), to yield the one-off long-run productivity shocks listed in Table A10.4. Although these shocks are applied only in the long run, they are important for short run behaviour (our object here) because they raise the return on installed capital and hence they stimulate investment.

The results from the long-run simulation are provided in Table A10.3. They show the expected allocative efficiency gains, reflected here in a rise in GDP, aided by increased returns on installed physical capital that induce greater investment and therefore larger net inflows on the capital account. Home consumption switches away from home produced goods, the relative prices of home produced goods fall, yielding the predicted real depreciation. The principal downside of the reforms is the long-run shift of activity out of agriculture into manufacturing and services and the associated decline in land rents. Associated with this shift, a substantial relocation of workers from agriculture to the modern sector will therefore be required.

Although the trade policy regime of 2001 advantaged food processing, 'other crops', fisheries and light manufacturing, apart from the smaller 'beverages' industry, it is the manufacturing sectors that are the robust beneficiaries of the unilateral trade liberalisation. This is surprising, given 
that the protection of the manufacturing sectors is also set to decline. This result arises because both manufacturing sectors commit approximately half their total costs to inputs in the same product category and 10 to 15 per cent of those to imports; and competing imports, even though they are from the same sector, are differentiated from home products (see Tyers and Rees, Chapter 9). Under these conditions the tariff reductions on imported intermediates have a direct effect on home industry total costs. Reductions of tariffs on competing, but differentiated, imports have only an indirect effect, the magnitude of which depends on the elasticity of substitution between the two. Indeed, for manufacturing, it turns out that the input cost effect of tariff reductions is considerably greater than that of the loss of protection against competing imports. Cost reductions of similar origin are the reason for similar gains accruing to the domestic transport services sector.

The reforms result in the most substantial reductions in protection to China's food processing sector and therefore lead to long-run contractions in that sector and in the local supply of its inputs (especially rice and 'other crops'). The more income elastic and lightly protected agricultural sectors, the 'beverages' group and livestock, expand. Labour is assumed to be perfectly mobile between sectors, so that our results indicate the labour movement needed in order to achieve the maximum gain from the reforms. In the long run, employment in food processing falls by 7 per cent, in rice production by 4 per cent and in 'other crops' by 2 per cent. Workers lost from these sectors are re-employed primarily in manufacturing and services.

When reform-driven productivity improvements are included in the long-run analysis, the economic effects of the reforms are greatly amplified, even though the assumed productivity changes are one-off and modest. The GDP increase is almost ten times larger, domestic investment is four times larger, as is the return on installed capital that will drive short term investment. Increases in sectoral expansions are largest in manufacturing and services with productivity growth in services having widespread effects through their role as intermediates. The contraction in the agricultural sector is much reduced, with the beverages, livestock and fisheries sectors now showing robust expansion. 


\section{Simulated short-run effects}

In the short run, the standard closure is as indicated in Table A10.4. Monetary authorities in China, Vietnam and the Rest of the World are assumed to maintain fixed exchange rates against the US\$. The other regions identified adopt price level (CPI) targeting. Capital controls are assumed to be rigid in China and Vietnam, but they are non-existent in the other regions. In the labour markets of China and Vietnam, nominal wages are assumed to be sticky. Full short run rigidity is assumed in the industrial countries, while nominal wages are assumed to be fully flexible elsewhere in Asia and the developing world. As to fiscal policies (not shown in the table), government spending in all regions is assumed to absorb a fixed proportion of GDP and the rates of direct and indirect tax are constant, so that government deficits vary in response to shocks.

Three macroeconomic policy regimes are considered.

- The 'standard': rigid capital controls, a fixed exchange rate and fixed direct and indirect tax rates.

- No capital controls, a fixed exchange rate and fixed direct and indirect taxes.

- No capital controls, a floating exchange rate with monetary policy targeting the GDP price, and fixed direct and indirect tax rates (Table A10.4).

In addition, two different assumptions are made about investment and the services capital stock. In a pessimistic scenario, investors do not see the long-run benefits of productivity gains that would accompany trade reform, and there is no immediate effect from reforms in services trade. In an optimistic counterpart, investors are motivated by the long-run return on installed capital listed in the second column of Table A10.3. Moreover, drawing on the conclusions from studies by Dee and Hanslow (2000) and Verikios and Zhang (2001), service trade reforms are assumed to result in the short run bolstering of the capital stock in finance and communications indicated in Table A10.2. Not surprisingly, the short-run effects of China's WTO commitments prove to be heavily dependent on its macroeconomic policy regime and these associated productivity and capital stock changes. 
Indeed, the effects range from the contraction alluded to in the introduction through to a substantial short run expansion.

The effects of capital controls and the choice of the monetary policy target

In broad terms, the behaviour of the model in the short run with rigid capital controls retained can be represented as in Figure 10.6. The upper diagram represents the domestic capital market and the lower one the domestic market for foreign products. These markets are linked by the requirement that, for a balance of payments, net flows on the capital account must mirror those on the current account. Net demand for foreign products (the downward sloping line in the lower diagram, $N M=M-X$ ) depends on the relative price of foreign goods. For this purpose we define the real exchange rate as in Equation 1 as the common currency ratio of the price of home goods to the price of foreign goods. Net imports depend positively on this real exchange rate and negatively on its inverse (the common currency, foreign to home product price ratio). This excess demand curve is shifted to the right by an increase in GDP, $Y$, or a reduction in protection, $\tau$. The real exchange rate is then determined by the balance of payments requirement that net inflows on the capital account must equal net outflows on the current account, $\mathrm{KA}=-\mathrm{CA}=\mathrm{NM}=\mathrm{M}-\mathrm{X}{ }^{12}$

The trade liberalisation reduces $\tau$ and shifts NM to the right. With tight capital controls, the current account balance cannot change. The shock therefore raises the relative price of foreign goods in the home market and depreciates the real exchange rate. If the nominal exchange rate is the target of monetary policy and the home economy is small by comparison with its trading partners ( $\mathrm{P}^{*}$ is unaffected) then a fall in $\mathrm{P}^{\mathrm{r}}$ (a deflation) is required. This must be brought about by a monetary contraction in defence of the exchange rate. To the extent that wages adjust more sluggishly than product prices, the deflation causes the real wage to rise. Were the real depreciation the only consequence of the liberalisation shock, its effects would be contractionary. Fortunately, this need not be the case. The trade reform brings gains in allocative efficiency. ${ }^{13}$

However, when capital controls remain rigid and the exchange rate is fixed, these allocative gains are insufficient to offset the contractionary 
effects of the deflation. This can be seen from the first column of Table A10.5. The real depreciation is substantial and the deflation required is of the order of 2 per cent per year. The production real wage rises by half this and employment falls. Investment demand responds to the expectation of higher real returns to installed capital in the future by shifting outward (Figure 10.6). The loss of tariff revenue drives the government deficit higher, reducing domestic saving, and further reinforcing the outward shift of the net foreign investment demand (NFI) curve. But the rigidity of the capital controls causes this to simply push up the domestic interest rate and so real investment falls. Output falls in all sectors except beverages, energy, manufacturing and transport. Manufacturing gains in the short run for the same reasons it gains in the long run-cheaper imported inputs. Therefore, under these policy circumstances the net gains from trade reform are not robust in the short run-at least when pessimistic assumptions are made about productivity effects and services reform.

If the capital controls are removed, the corresponding liberalisation shock is as depicted in Figure 10.7 (the results are shown in column 2 of Table A10.5). Here, reduced protection also yields a gain in allocative efficiency but this time it is large enough to generate a net gain in GDP, reinforcing the rightward shift in the net imports curve in the lower diagram. In this case, however, the absence of capital controls allows investment to flow in, responding to the increase in the expected long-run return on installed capital. The increased inflow on the capital account relaxes the balance of payments constraint in the lower diagram and allows a shift toward net imports. The net effect on the real exchange rate depends on whether the capital account shift, which raises the net supply of foreign goods, is larger or smaller than the increase in their net demand due to the tariff reduction and the rise in domestic income. In this case, the increase in net demand is dominant and the real exchange rate still depreciates, albeit to a lesser extent than in the presence of capital controls. Thus, when capital controls are weak or non-existent, trade liberalisation attracts increased inflows on the capital account in order to mitigate the real depreciation and associated GDP price deflation that are its inevitable consequences.

In the third column of Table A10.4 the target of monetary policy is the GDP price, so that the nominal exchange rate is allowed to depreciate. This removes the deflation that must accompany a fixed exchange rate and 
hence reduces the rise in the production real wage due to the reforms. The GDP gain is therefore almost doubled and now only the processed food sector contracts in the short run. Interestingly, the additional investment and greater employment generated with the policy regimes of columns 2 and 3 ensure that real land rents rise in the short run.

Finally, the three right hand columns of Table A10.4 indicate the short-run effects of the WTO accession reforms under the same three policy regimes but with the more optimistic ancillary effects of those reforms (Table A10.2) included. There are two key differences. First, investors are motivated by the effects of increased productivity in response to the reforms in the long run and, second, services reforms see a short run increment to the capital stocks in the financial and communications sectors. These changes cause substantial increases in investment and, in association, they cause larger net inflows on the capital account; they also boost the construction sector and reduce the cost of service inputs to other sectors. Overall, expansions are consistently larger in these cases as is the demand for the sectoral relocation of workers. These are due, in part, to the increases in total employment that occur because of sticky nominal wages. The upward movement in nominal wages is slower than that in labour productivity, expanding aggregate labour demand by up to 2 per cent.

\section{Short run sectoral impacts}

The key determinants of the sectoral mix of changes in the economy are the tariff reductions; these reduce product prices in affected sectors and the size of the resulting short run real depreciation, which reduces non traded (largely services) prices relative to traded goods prices. When capital controls are tight the real depreciation is comparatively large. Traded sectors, such as light manufacturing, are advantaged, while non traded services sectors, such as construction and dwellings, are disadvantaged. On the other hand, when capital controls are ineffective, manufacturing gains are smaller and the non traded services sectors gain. Processed food suffers because of the decline in its protection and other agricultural industries contract as that sector demands fewer local inputs. When the macroeconomic policy regime is expansionary, however, only 
the processed food sector contracts. And, when the optimistic ancillary effects are included, the decline in the processed food sector becomes trivially small, ensuring gains to the agricultural sector as a whole. This result is quite important since, sensing losses due to reduced protection, the farm sector opposes the reforms. Yet, if the reforms were embraced along with expansionary macroeconomic policy, the farm sector would be a net gainer.

\section{Worker relocation demand in the short run}

The sectors defined for the purpose of our simulations are here aggregated for ease of comparison with the classification of employment by China's National Bureau of Statistics. In facilitating this comparison, it has occasionally been necessary to aggregate sectors in both classifications. The result is the seven sectoral groupings in Table A10.6. Also listed are the maximum and average annual changes in employment by sector, drawn from official statistics since 1978. The detailed official record of annual changes in employment by sector is provided in the Appendix. These changes include some of extraordinary magnitude, most especially the growth in employment in the services sectors in 1984. We discount these as due to changes in measurement in that year. There have, however, also been some extraordinary employment growth periods since then, including the service employment expansions of 1993 and 1994. Of course, the services sectors were considerably smaller then than they are now, and so the numbers of workers relocated to achieve those employment growth numbers were smaller than would now be required. Even so, these statistics suggest that China's capacity for the rapid sectoral relocation of workers has been considerable.

In the same table we show the range of simulated short run worker relocation demands associated with China's WTO accession reforms. In interpreting these it must be borne in mind that employment in China is endogenous in these simulations. From Table A10.5, depending on the macroeconomic policy settings, it either contracts a quarter of a per cent or expands by almost 2 per cent. This opens the possibility that, at least in the short run, rural activity can expand at sufficient pace to retain its 
workers. When we combine the most expansionary policy scenario with the ancillary effects of productivity and services reform (Table A10.2), the expansion in overall employment permits employment in each sector to increase, as indicated in the final column of Table A10.6. Of course, there remains considerable redistribution of employment in these results, since the services sectors expand their labour use much more rapidly than does agriculture. Since we focus on the short run, we take no explicit account of technical change in Chinese agriculture. In other countries at the same stage of development this change has been labour saving, enabling the agricultural sector to shed workers at a considerable rate (Anderson et al. 2002).

Our contention that the macroeconomic policy environment is important in determining the pace of worker relocation demand is borne out in these results. In all sectors there is a stark contrast between employment growth under tight capital controls and a fixed exchange rate regime on the one hand and an investment policy that renders the capital controls ineffective, combined with a flexible exchange rate, on the other. When the ancillary shocks to productivity and services capital are included, this gulf widens further. In the case of this most optimistic of scenarios, employment growth exceeds the average since 1990 in all but two sectors and the excess is largest in construction and dwellings and transport services. These strong worker relocation demands nonetheless fall short of the maxima achieved in a single year in all sectors, even since 1990.

Yet the WTO accession reforms are but a small part of the pantheon of China's overall reform program, the bulk of which is growth enhancing. We not only exclude the trend of technology and associated organisational changes, as mentioned previously, but we take no account of the ongoing financial sector reforms and the continuing transformation of urban activity from the public to the private sector. Even in the case of China's WTO accession, we take no account of commitments by China's trading partners to reduce protection against its labour-intensive exports. These changes will improve China's terms of trade and stimulate its growth. Considering such omissions, worker relocation demand in a more expansionary policy environment could well approach, or even exceed, the high rates of change observed in the early 1990s. 
Finally, our simulations rest on the assumption that production and skilled workers in one sector are perfectly transformable into corresponding workers in other sectors. Because some workers have narrowly sectorspecific education and training and because sectoral relocation has high transaction costs, particularly for rural families, the actual transformability of production workers will remain imperfect (Sicular and Zhao 2002). Our results therefore place upper bounds on the economic performance results from the WTO accession reforms and, more importantly for our purpose, upper bounds on worker relocation demands in the short run.

\section{Conclusions}

Our chronicle of changes in economic performance, income distribution and internal migration in China suggests a recent slowing of employment growth in the modern sector and the 'bottling up' of labour in rural activities, widening the income gap between urban and rural workers. This has happened in spite of what our review suggests is a considerable relaxation of the worker registration, or hukou, system that has constrained internal migration in the past.

To examine the hypothesis that the slowdown in economic growth, and the pace of worker relocation in particular, is due at least in part to a restrictive macroeconomic policy regime, we adapt a comparative static multi-product, multi-region macroeconomic model. We use the model to compare the economic effects of a key element of China's current economic reform program, namely its commitments associated with its accession to the WTO, under a variety of macroeconomic policy regimes. These range from very restrictive capital controls, combined with a fixed exchange rate, to a regime with no capital controls (or the equivalent in FDI flexibility) and a flexible exchange rate. The results suggest these regimes make a difference of at least 1 per cent per year in GDP growth and at least 2 per cent per year in employment growth in the economy's modern sector. They therefore support our hypothesis, at least to the extent that the macroeconomic policy regime has contributed to a slowdown in the pace of expansion and worker relocation. Indeed, with an expansionary macroeconomic policy and optimistic assumptions about productivity 
effects associated with the WTO accession reforms and inter-sectoral worker transformability, simulated worker relocation demands from these reforms alone exceed the average of China's recent experience.

While we are confident about our conclusion that China's macroeconomic policy regime has reduced economic performance relative to its theoretical potential, it does not follow that we advocate the immediate elimination of capital controls and the adoption of a floating exchange rate. The latter has been advocated recently by government representatives in Japan and the US, including such significant players as the Chairman of the US Federal Reserve. ${ }^{14}$ We are more inclined to caution on the issue of the exchange rate, recognising that a float would be premature considering China's underdeveloped financial sector, its partially reformed banking industry and its still vulnerable state-owned enterprises. ${ }^{15}$ The fact that more flexibility would enhance China's growth should be taken as advocating the acceleration of the reform processes needed before a floating rate regime can be implemented. ${ }^{16}$

\section{Notes}

1 The contractionary effects of deflation do not end there (Bordo and Redish 2003).

2 See Hertel (1997) for the original specification.

3 lanchovichina and Martin (2001, 2002b) also examine the effects of WTO accession on labour relocation demand and they offer an explicit analysis of the HRS. Their analysis is strictly long run, however, ignoring the short run contractionary effects of macroeconomic policy emphasised here.

4 See Banister and Taylor (1989); Chai and Chai (1997); Hui (1989); Seeborg, Jin and Zhu (2000); and Multinational Monitor.

5 See Banister and Taylor (1989); Hui (1989); Seeborg, Jin and Zhu (2000).

6 See Banister and Taylor (1989); Hong Kong Liaison Office (IHLO). China's unemployment statistics measure only the urban unemployed.

7 In 1984, it was estimated that about 40 per cent of workers in the countryside were redundant. See Chai and Chai (1997).

8 The effect of these restrictions was to tend to leave marginal urban residents underqualified for their jobs while migrants from rural areas tend to be overqualified. Meng and Zhang (2001) estimate these rates of under and over qualification at 22 per cent for urban residents and 6 per cent for migrants from rural areas. 
9 Often quoted is the real effective exchange rate, which is a weighted average of bilateral real rates

$$
e_{i}^{R}=\sum_{j} E_{j}\left(\frac{P_{i}^{Y}}{P_{j}^{Y}}\right)\left(\frac{X_{j}+M_{j}}{X_{i}+M_{i}}\right)
$$

where $\mathrm{Xi}$ and $\mathrm{Mi}$ are region i's total values of exports and imports, respectively.

10 The analysis by Yang and Tyers $(2000,2001)$ suggests that the magnitudes of China's crisis period deflation might be understated by official statistics.

11 A detailed description of the original model is provided by Hertel (1997).

12 The net factor income component of the current account is zero at the outset because that is the assumption embodied in the construction of the original database.

13 To see these at least partially offsetting gains in allocative efficiency, it is necessary to use a multi-commodity, general equilibrium framework such as used in this paper.

14 Interestingly, this pressure has tended to be for a revaluation of the RMB, which would benefit both Japan and the US in the short run. The shocks we examine yield real depreciations, however. Were these shocks dominant, we believe the fundamentals are more likely to support a devaluation of the RMB. A revaluation would be justified only in the event of Chinese investment demand taking on 'bubble' characteristics, capital controls notwithstanding.

15 See the discussion on this point by Edwards (2003).

16 See both Roberts and Tyers (2003) and Edwards and Levy-Yeyati (2003).

\section{References}

Anderson, K., Huang, J. and lanchovichina, E., 2002. 'Long-run impact of China's WTO accession on farm-non-farm income inequality and rural poverty', Paper presented at World Bank Conference on China's WTO Accession, Policy Reform and Poverty Alleviation, Beijing, 28-29 June. Banister, J. and Taylor, J.R., 1989. 'China: surplus labour and migration', Asia-Pacific Population Journal, 4(4):3-20.

Bordo, M.D. and Redish, A., 2003. Is deflation depressing? Evidence from the classical gold standard, National Bureau of Economic Research Working Paper No. W9520, Cambridge, Massachusetts.

Burgess, S. and Mawson, D., 2003. Aggregate growth and the efficiency of labour reallocation, Discussion Paper No. 3848, Centre for Economic Policy Research, London. 
Canadian Immigration and Refugee Board, accessed 9 December 2002. China: Internal migration and the floating population http://www.irb. gc.ca/en/Researchpub/research/publications/chn11_e.htm.

Chai, J.C.H. and Chai, B.K., 1997. 'China's floating population and implications', International Journal of Social Economics, 24(7-8-9):1,038-51.

Chan, K.W. and Zhang, L., 1999. 'The Hukou system and the rural-urban migration in China: processes and changes', The China Quarterly, Dec 0(160):818-55.

Chand, S., 1999. 'Trade liberalisation and productivity growth: timeseries evidence from Australian manufacturing', The Economic Record, 75(228):28-36.

Chand, S., McCalman. P. and Gretton, P., 1998. 'Trade liberalisation and manufacturing industry productivity growth', Paper in Productivity Commission and Australian National University, Microeconomic Reform and Productivity Growth, Workshop Proceedings, AusInfo, Canberra:239-81. Dee, P. and Hanslow, K., 2000. Multilateral liberalisation of services trade, Productivity Commission of Australia, Canberra.

Dolven, B., 2003. 'Take our workers, please', Far Eastern Economic Review, 27 (February):24-26.

Edwards, S., 2003. 'China should not rush to float its currency', Financial Times, 3 August.

-- and Levy-Yeyati, E., 2003. Flexible exchange rates as shock absorbers, NBER Working Paper No.W9867, Cambridge, Massachusetts.

Garnaut, R., 1999. 'China after the East Asian crisis', China Update 1999 Conference Papers, National Centre for Development Studies, Australian National University, Canberra.

Gehlhar, M.J., 2002. 'Hong Kong's re-exports', Dimaranan, B.V., McDougall, R.A., (eds), Global Trade, Assistance and Production: the GTAP 5 Data Base, Center for Global Trade Analysis, Purdue University, West Lafayette, www.gtap.agecon.purdue.edu/databases/v5/v5_doco.asp. Hertel, T.W. (ed.), 1997. Global Trade Analysis Using the GTAP Model, Cambridge University Press, New York.

Hong Kong Liaison Office (IHLO), accessed 4 December 2002. China and the WTO, update and analysis, May. Available online at http://www.ihlo. org/item3/item3h-3.htm. 
Hui, D., 1989. 'Rural labour force transition and patterns of urbanisation in China', Asia Pacific Population Journal, 4(3):41-51.

lanchovichina, E. and Martin, W., 2001. 'Trade liberalisation in China's accession to the WTO', Journal of Economic Integration 16(4):421-45.

--, 2002a. Economic impacts of China's accession to the WTO, World Bank Policy Research Working Paper No. 3053, World Bank, Washington DC. --, 2002b. 'Evaluating accession to WTO by China and Chinese Taipei', Paper presented at the Fifth Annual Conference on Global Economic Analysis, Taipei, June.

Lee, JW. and Rhee, C., 1998. 'Social impacts of the Asian crisis: policy challenges and lessons', Paper prepared for the United Nations Development Programme Human Development Report Office, New York.

Lin, H.C., Chung, L., and Liou, R.W., 2002. 'Taiwan', Chapter $11 \mathrm{~F}$ in Dimaranan, B.V., McDougall, R.A. (eds), Global Trade, Assistance and Production: the GTAP 5 Data Base, Center for Global Trade Analysis, Purdue University, West Lafayette. Available online at www.gtap.agecon. purdue.edu/databases/v5/v5_doco.asp.

Lozada, C., 2002. 'Globalisation reduces inequality in China', The NBER Digest, National Bureau of Economic Research, Cambridge, Massachusetts.

Meng, X., 1998. 'Recent development in China's labour market', China Update 1998 Conference Papers, National Centre for Development Studies, Australian National University, Canberra.

Meng, X. and Zhang, J., 2001. 'The two-tier labour market in urban China: occupational segregation and wage differentials between urban residents and rural migrants in Shanghai', Journal of Comparative Economics, 29(3):485-504.

Multinational Monitor, 2002. 'Sewing up the Chinese market: the effect of WTO entry on the Chinese rural sector'. Available online at www. multinationalmonitor.org/mm2000/00may/weil.html (accessed 4 December 2002).

National Bureau of Statistics, 2001, 2002. China Statistical Yearbook, China Statistics Press, Beijing.

Roberts, I. and Tyers, R., 2003. 'China's exchange rate policy: the case for greater flexibility', Asian Economic Journal, 17(2):157-86. 
Seeborg, M.C., Jin, Z., and Zhu, Y., 2000. 'The new rural-urban labour mobility in China: causes and implications', The Journal of SocioEconomics, 29:39-56.

Sicular, T. and Zhao, Y., 2002. 'Labor mobility and China's entry to the WTO', Paper presented at the conference on WTO Accession, Policy Reform and Poverty Reduction, Beijing, 26-28 June.

Stoeckel, A., Tang, K.K., and McKibbin, W., 1999. 'The gains from trade liberalisation with endogenous productivity and risk premium effects', Technical Paper prepared for seminar: Reasons versus Emotion: Requirements for a Successful WTO Round, Seattle, 2 December.

Tyers, R. and Rees, L., 2000. 'Capital-skill complementarity and wage outcomes following technical change in a global model', Oxford Review of Economic Policy, 16(3):23-41.

--, 2001. 'Short run global effects of US 'new economy' shocks: the role of capital-skill complementarity', Paper presented at the Fourth Annual Conference on Global Economic Analysis, Purdue University, West Lafayette, 27-29 June. http://ecocomm.anu.edu.au/people/rod.tyers Verikios, G. and Zhang, X., 2001. 'The economic effects of removing barriers to trade in telecommunications and financial services', Paper presented at the Fourth Annual Conference on Global Economic Analysis, Purdue University, West Lafayette, 27-29 June.

Wang, Z., Zhai, F., and Xu, D., 2002. 'China', in B.V. Dimaranan and R.A. McDougall (eds), Global Trade, Assistance and Production: the GTAP 5 Data Base, Center for Global Trade Analysis, Purdue University, West Lafayette, www.gtap.agecon.purdue.edu/databases/v5/v5_doco.asp.

Yang, Y., 1998. 'China in the middle of the East Asian crisis-export growth and the exchange rate', China Update 1998 Conference Papers, National Centre for Development Studies, The Australian National University, Canberra.

Yang, Y. and Tyers, R., 2000. China's post-crisis policy dilemma: multi-sectoral comparative static macroeconomics, Working Papers in Economics and Econometrics No. 384, The Australian National University, Canberra. , 2001. 'The Asian crisis and economic change in China'. Japanese Economic Review, 52(4):491-520.

Zhao, Y., 2000. 'Rural to urban labour migration in China: past and present', in L. A. West and Y. Zhao (eds), Rural Labour Flows in China, University of California Press, Berkeley:15-33. 


\section{Appendix}

Table A10.1 Official price level changes since the Asian crisis

\begin{tabular}{lcccc}
\hline & & & & \\
1997 & Consumer prices & Retail prices & Ex factory prices & GDP deflator \\
1998 & 2.8 & 0.8 & -0.3 & 0.9 \\
1999 & -0.8 & -2.6 & -4.1 & -2.6 \\
2000 & -1.4 & -3.0 & -2.4 & -2.4 \\
2001 & 0.4 & -1.5 & 2.8 & 1.0 \\
& 0.7 & -0.8 & -1.3 & 0.0 \\
\hline
\end{tabular}

Source: National Bureau of Statistics, 2002. China Statistical Yearbook, China Statistics Press, Beijing:Tables 3-3 and 9-1. 


\section{Table A10.2 Ancillary effects of WTO trade reforms ${ }^{\mathrm{a}}$}

\author{
Long-run total factor \\ productivity rises associated with \\ reduced protection, ${ }^{\mathrm{a}}$ per cent
}

\author{
Short-run effect of reduced \\ services protection on capital \\ accumulation in financial and \\ communications, ${ }^{\mathrm{c}}$ per cent/year
}

\begin{tabular}{ll} 
Rice & 1.0 \\
Beverage & 1.0 \\
Other crops & 1.0 \\
Livestock & 1.0 \\
Food & 2.0 \\
Fish & 0 \\
Minerals & 0 \\
Energy & 0 \\
Light manufacturing & 1.5 \\
Heavy manufacturing & 3.0 \\
Transport services & 1.0 \\
Infrastructural services & 1.0 \\
(electricity, gas, water) & 2.0 \\
Construction and dwellings & \\
Other (including financial & \\
and communications) & 5.0 \\
\hline
\end{tabular}

Notes: a These are supplementary exogenous shocks applied, where indicated, along with the tariff reductions. They incorporate the findings of other research, particularly on the effects of services reform.

${ }^{b}$ Estimates based on the results from research by Chand et al. (1998), Chand (1999) and Stoeckel et al. (1999).

' Estimated one year effect, based on the results from research by Dee and Hanslow (2000) and Verikios and Zhang (2001).

Sources: Chand, S., 1999. 'Trade liberalisation and productivity growth: time-series evidence from Australian manufacturing', The Economic Record, 75(228):28-36; Chand, S., McCalman. P. and Gretton, P., 1998. 'Trade liberalisation and manufacturing industry productivity growth', Paper in Productivity Commission and Australian National University, Microeconomic Reform and Productivity Growth, Workshop Proceedings, AusInfo, Canberra:239-281; Stoeckel, A., Tang, K.K., and McKibbin, W., 1999. 'The gains from trade liberalisation with endogenous productivity and risk premium effects', Technical Paper prepared for seminar: Reasons versus Emotion: Requirements for a Successful WTO Round, Seattle, 2 December 1999; Dee, P. and Hanslow, K., 2000. Multilateral liberalisation of services trade, Productivity Commission of Australia, March; Verikios, G. and Zhang, X., 2001. 'The economic effects of removing barriers to trade in telecommunications and financial services', Paper presented at the Fourth Annual Conference on Global Economic Analysis, Purdue University, West Lafayette, 27-29 June. 
Table A10.3 Simulated long-run effects of a unilateral liberalisation of China's 2001 trade policy regime ${ }^{a}$

\begin{tabular}{|c|c|c|}
\hline Change in: & $\begin{array}{l}\text { No ancillary effects } \\
\text { on productivity or } \\
\text { services capital }\end{array}$ & $\begin{array}{c}\text { With ancillary effects } \\
\text { on productivity and } \\
\text { services capital }^{b}\end{array}$ \\
\hline Terms of trade (per cent) & -1.25 & -1.52 \\
\hline Real effective exchange rate, $e^{R}$ (per cent) & -1.98 & -2.56 \\
\hline Real exchange rate against USA, e (per cent & -1.81 & -2.37 \\
\hline Global interest rate, $r$ (per cent) & 0.10 & 0.05 \\
\hline Investment premium factor, $(1+\pi)$ (per cent) & 0.00 & 0.00 \\
\hline Home interest rate, $r$ (per cent) & 0.10 & 0.05 \\
\hline Return on installed capital, $r$ (per cent) ${ }^{c}$ & 1.30 & 4.98 \\
\hline Real domestic investment, I (per cent) & 0.95 & 3.85 \\
\hline Balance of trade, $\mathrm{X}-\mathrm{M}=-\mathrm{KA}=-\left(\mathrm{I}-\mathrm{S}_{\mathrm{D}}\right)$ (US\$ bn) & -10.87 & -56.51 \\
\hline \multicolumn{3}{|l|}{ Real gross sectoral output (per cent) } \\
\hline Rice & -3.29 & -2.54 \\
\hline Beverage & 2.77 & 3.33 \\
\hline Other crops & -1.25 & -0.36 \\
\hline Livestock & 0.03 & 1.32 \\
\hline Food & -5.41 & -4.32 \\
\hline Fish & -0.17 & 0.35 \\
\hline Minerals & 0.88 & 2.38 \\
\hline Energy & 0.78 & 0.95 \\
\hline Light manufacturing & 1.49 & 2.26 \\
\hline Heavy manufacturing & 1.08 & 4.60 \\
\hline Transport & 1.44 & 2.87 \\
\hline Infrastructure services & 0.34 & 2.25 \\
\hline Construction and dwellings & 0.73 & 3.46 \\
\hline Other services & 0.76 & 4.96 \\
\hline Real GDP, Y & 0.41 & 3.31 \\
\hline \multicolumn{3}{|l|}{ Unskilled wage and employment (per cent) } \\
\hline Nominal (unskilled) wage, $\mathrm{W}$ & -0.42 & 1.85 \\
\hline Production real wage, $\mathrm{W}=\mathrm{W} / \mathrm{P}^{\mathrm{Y}}$ & 1.51 & 4.53 \\
\hline Employment, $\mathrm{L}^{\mathrm{D}}$ & 0.00 & 0.00 \\
\hline \multicolumn{3}{|l|}{ Unit factor rewards CPI deflated (per cent) } \\
\hline Land & -2.65 & -1.39 \\
\hline Unskilled labour (those employed) & 1.27 & 4.08 \\
\hline Skilled labour & 1.38 & 4.22 \\
\hline Physical capital & 1.24 & 4.04 \\
\hline Natural resources & 1.20 & 2.65 \\
\hline
\end{tabular}

Notes: a All results in this table are based on the adoption of fiscal policy 1: government spending is held constant as a share of GDP and the revenue lost from tariff reform is not made up in other taxes, so the fiscal deficit expands. Key exogenous variables are highlighted as per the long-run closure discussed in the text.

${ }^{b}$ For these additional shocks, see Table A10.4.

Source: Model simulations described in the text. 
Table A10.4 Short-run closure ${ }^{a}$

Notes: ${ }^{\text {a }}$ The expected future return on installed capital is exogenous in the short run, determined in a separate long-run solution. There are three macroeconomic policy regimes for China, with (1) the most restrictive and (3) the most expansionary.

b The nominal money supply is endogenous in each case, the corresponding exogenous variable being the listed target.

c When the nominal wage is assumed flexible it is endogenous and the corresponding exogenous variable is the employment level. When it is sticky or rigid, Equation 2 is activated and the employment level is endogenous.

${ }^{d}$ Capital controls are assumed to maintain a rigid net inflow of foreign investment on the capital account. When KA = I-SD is made exogenous to represent this, an interest premium opens between the domestic and international capital markets. This premium becomes endogenous. Effectively, the home and foreign capital markets are separated and clear at different interest rates. Where the capital account is flexible (open), this implies that private flows on the capital account are permitted at any level. KA $=$ I-SD is then endogenous and the home interest premium is exogenous (unchanged by any shock). This means that the home interest rate then moves in proportion to the rate that clears the global savings-investment market. 
Trade reform, macroeconomic policy and sectoral labour movement in China

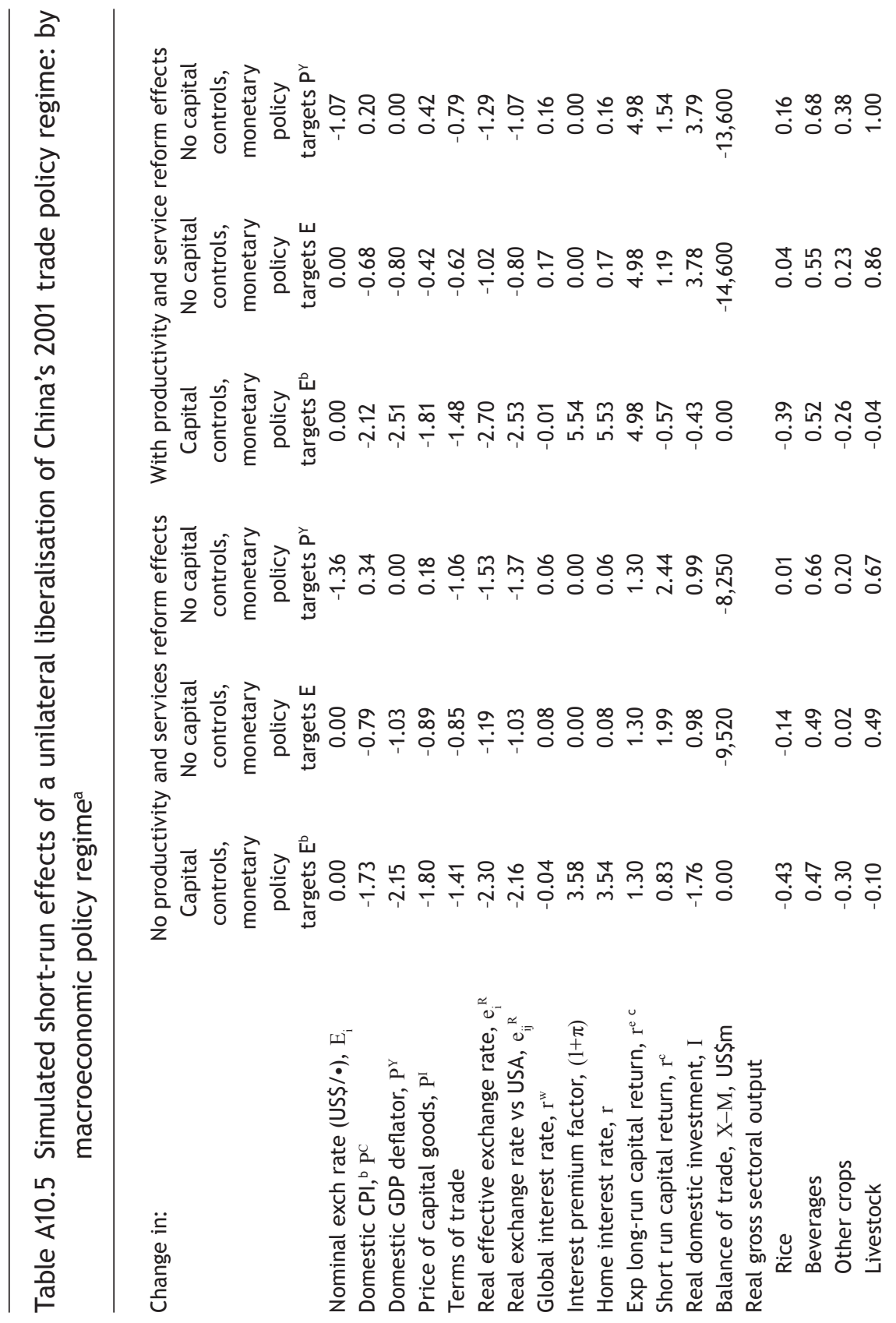


Agriculture and Food Security in China

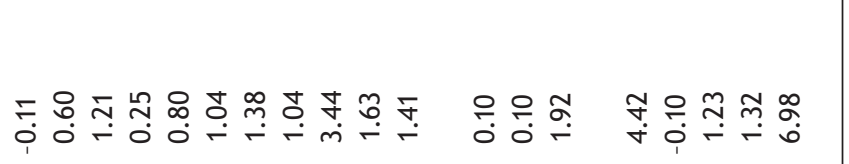

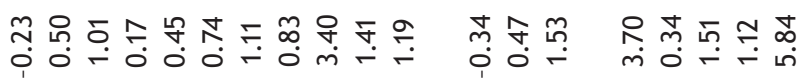

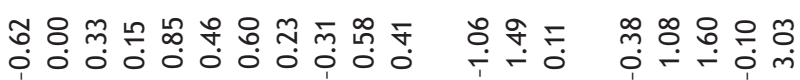

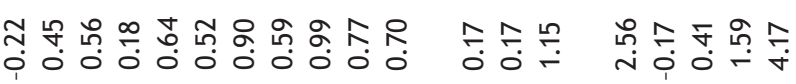

흘

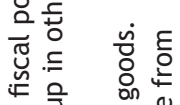

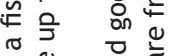

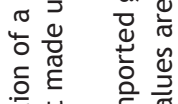

مै응

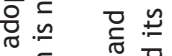

¿ E

ธับ 은

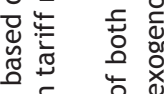

๘ั

을 艺

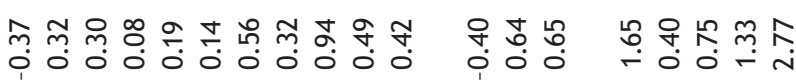

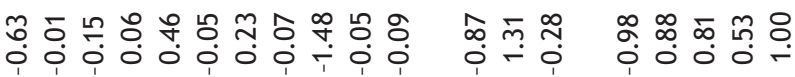

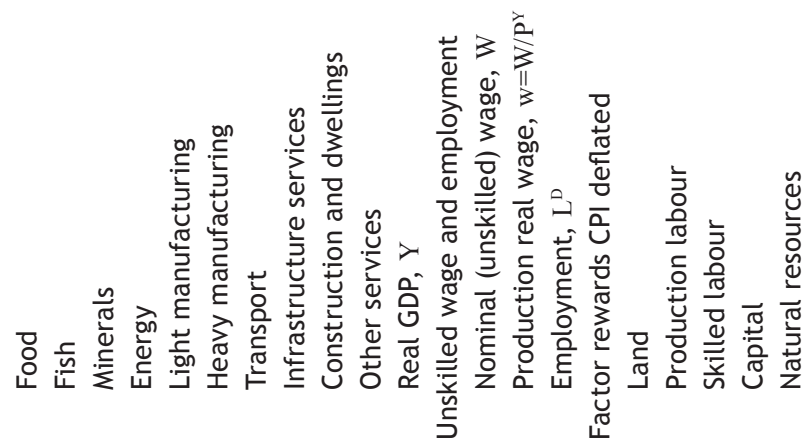

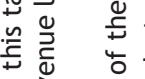

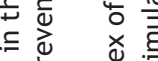

苛 :

这苦

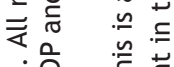

论

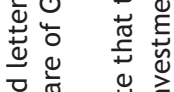

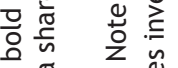

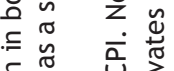

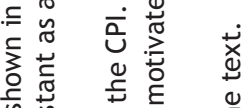

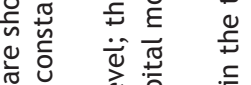

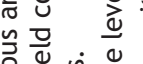

원.

on 0

Х. ख

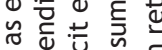

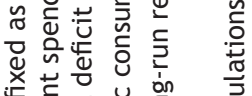

造焉苛

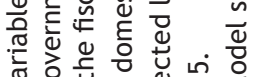

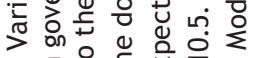

...

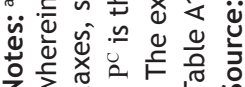




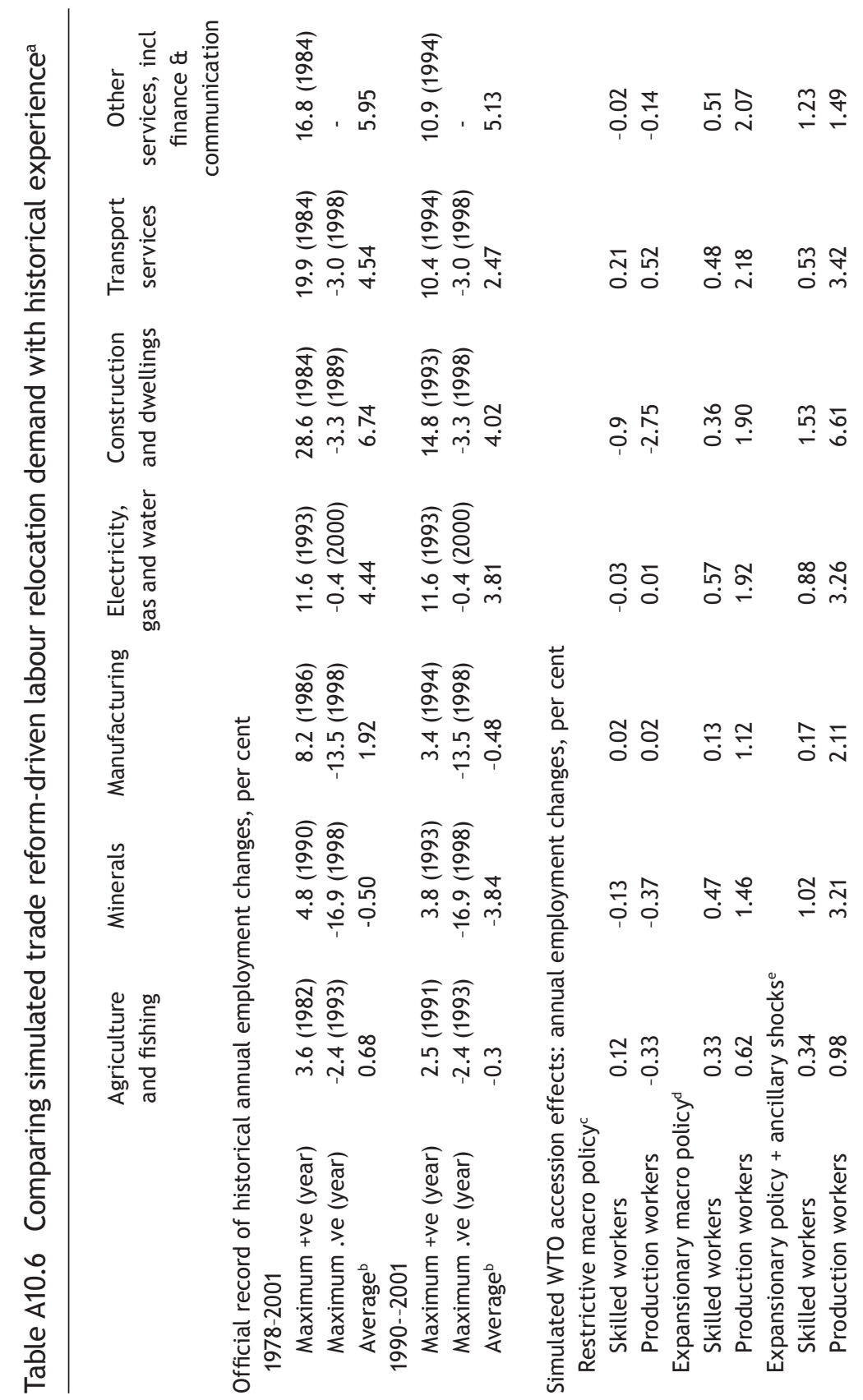




\begin{tabular}{|c|c|c|}
\hline 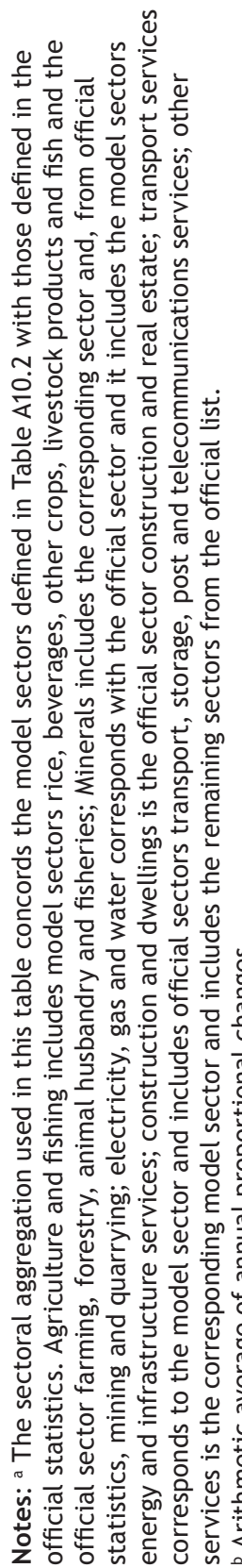 & 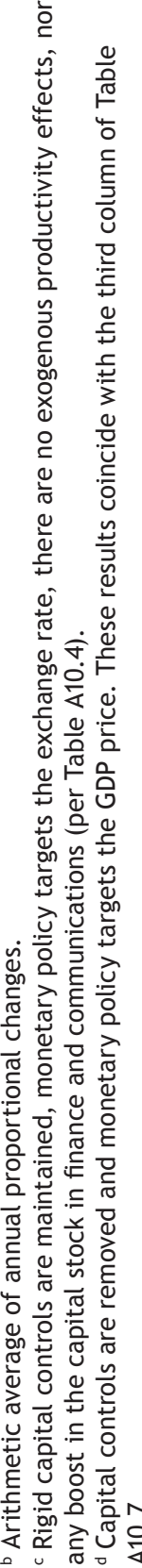 & 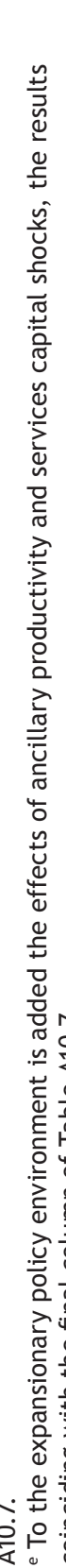 \\
\hline
\end{tabular}




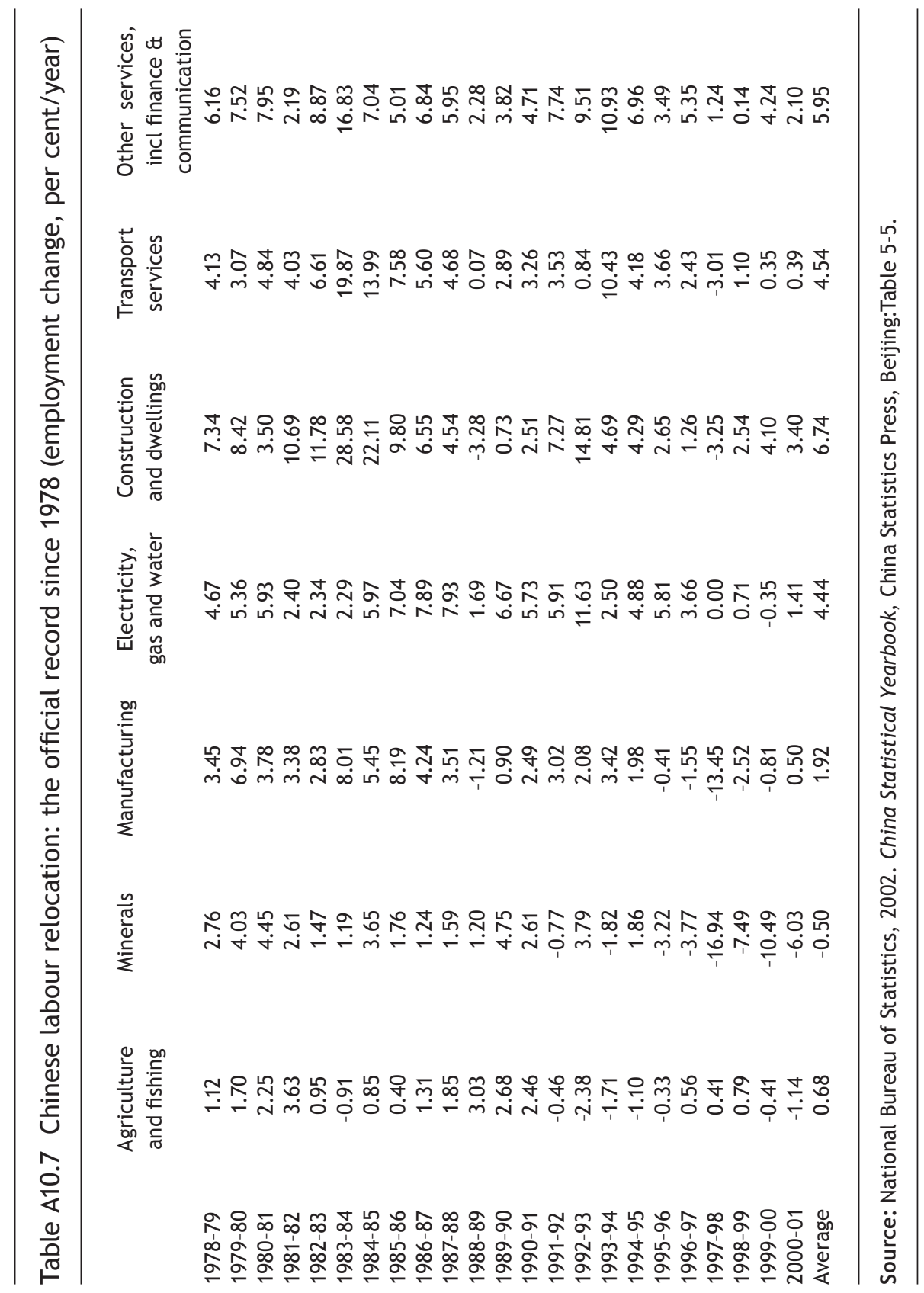


Figure 10A.1 Per capita annual income of urban and rural households, 1978-2001

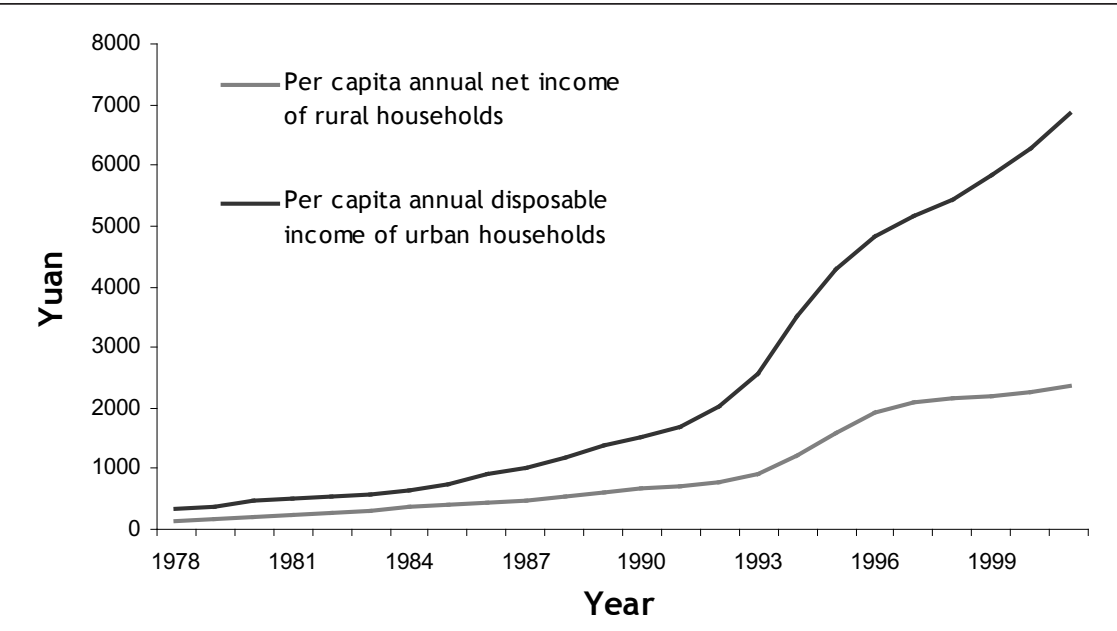

Source: National Bureau of Statistics, 2002. China Statistical Yearbook, China Statistics Press, Beijing:Table 10-3.

Figure 10A.2 Gap between urban and rural incomes, 1978-2001

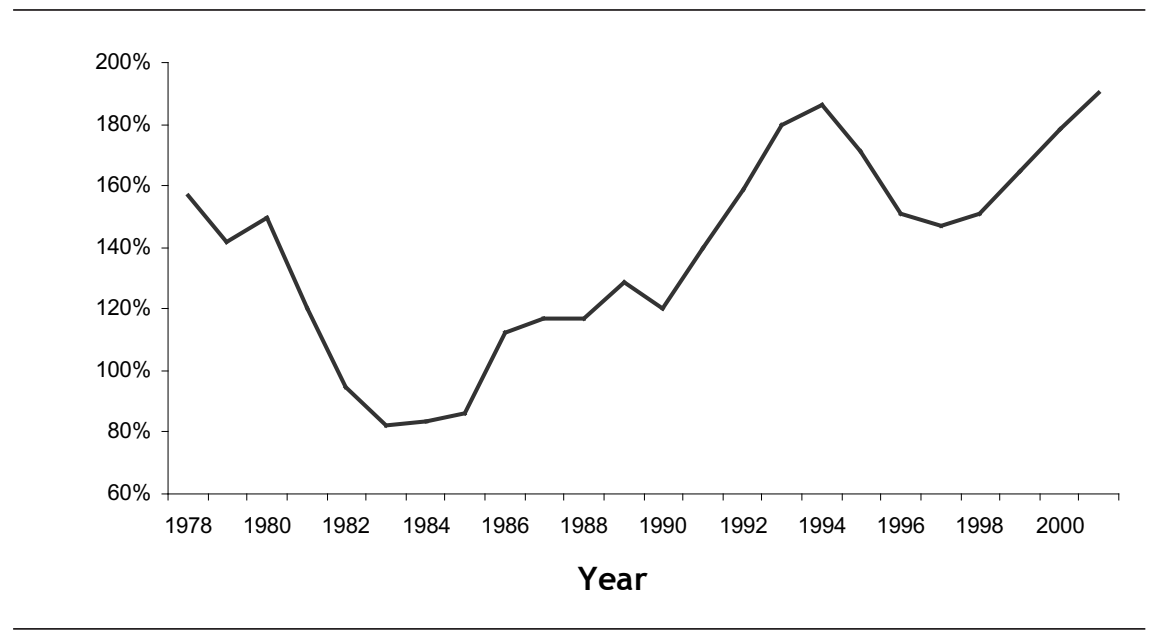

Source: National Bureau of Statistics, 2002. China Statistical Yearbook, China Statistics Press, Beijing:Table 10-3. 
Figure 10A.3 Employment by industry group, 1990-2001

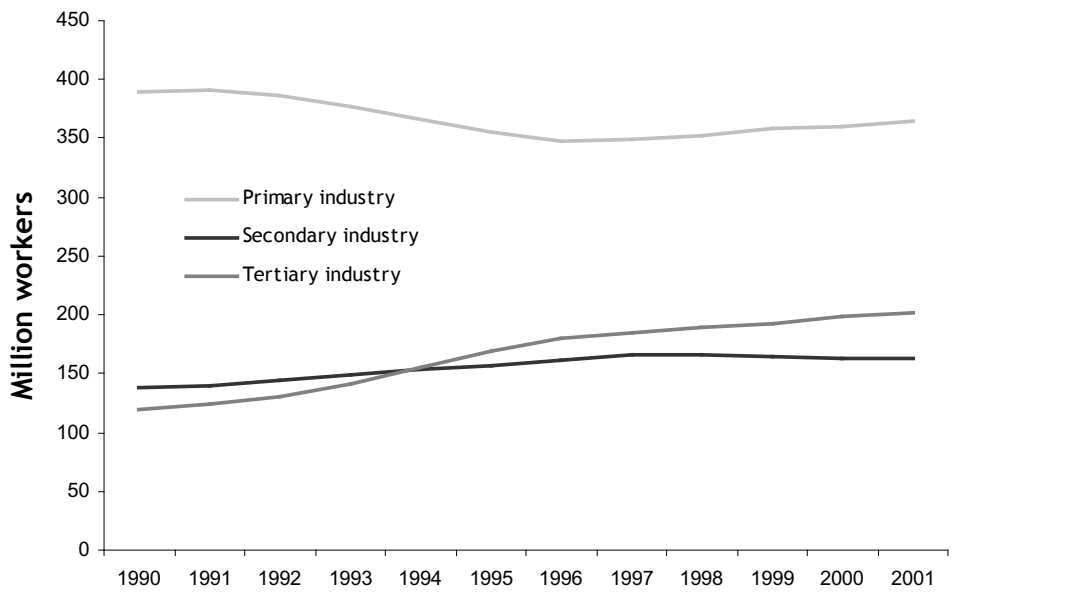

Source: National Bureau of Statistics, 2002. China Statistical Yearbook, China Statistics Press, Beijing:Table 5-2. Primary industry: farming, forestry, animal husbandry and fishery; secondary industry: mining, manufacturing, electricity, water, gas, construction; tertiary: all other industries.

Figure 10A.4 Official growth rate of real GDP, 1990-2001 (per cent/year)

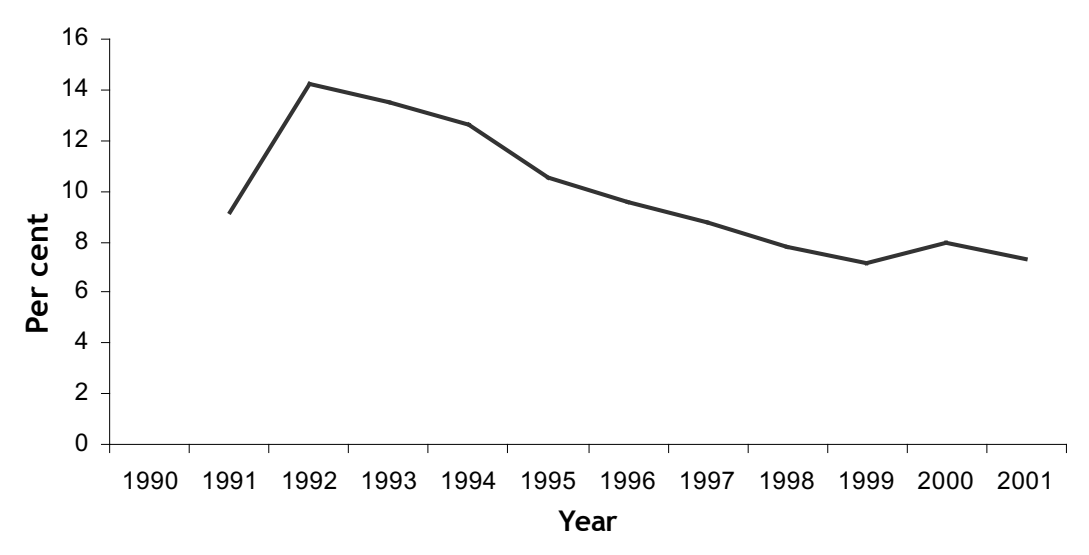

Source: National Bureau of Statistics, 2002. China Statistical Yearbook, China Statistics Press, Beijing:Table 3-3. 
Figure 10A.5 Official growth rate of average real manufacturing wage,1996-2000 (per cent/year)

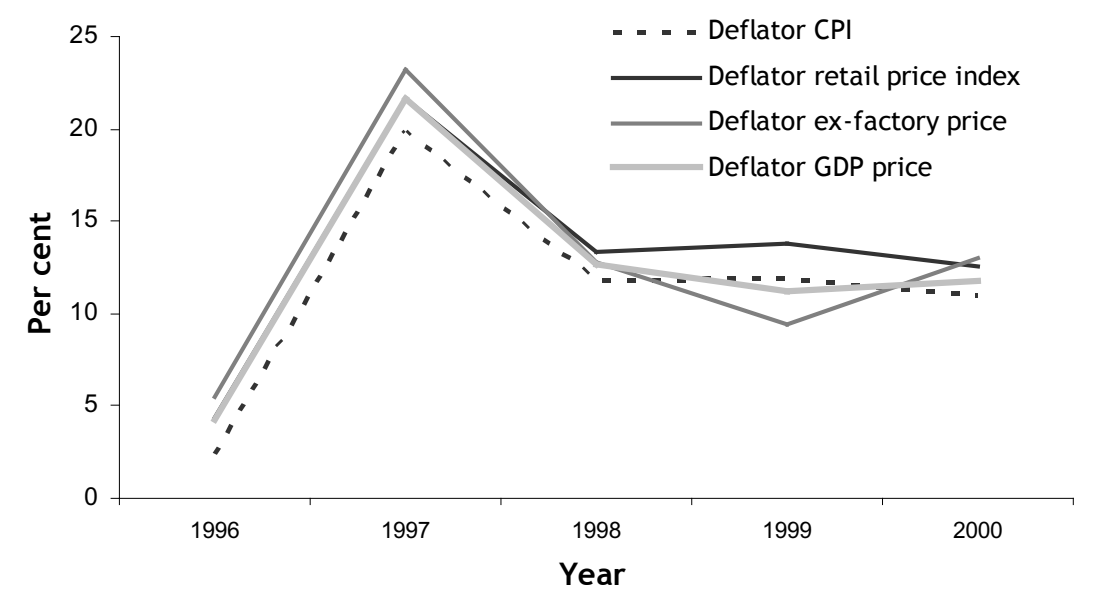

Source: National Bureau of Statistics, 2002. China Statistical Yearbook, China Statistics Press, Beijing:Table 5-22 and 9-1. 
Figure 10A.6 Trade reform with capital controls

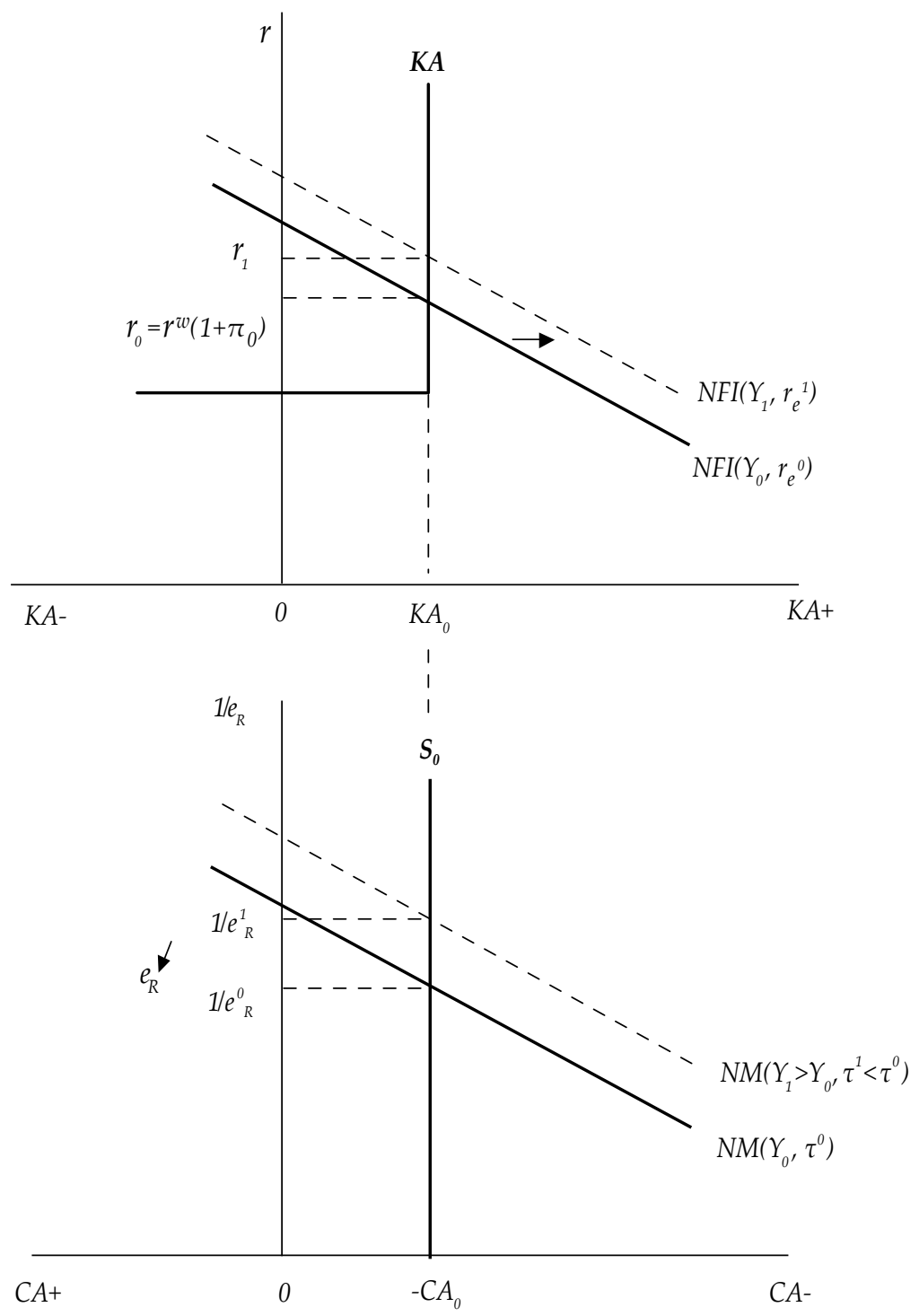


Figure 10A.7 Trade reform with no capital controls
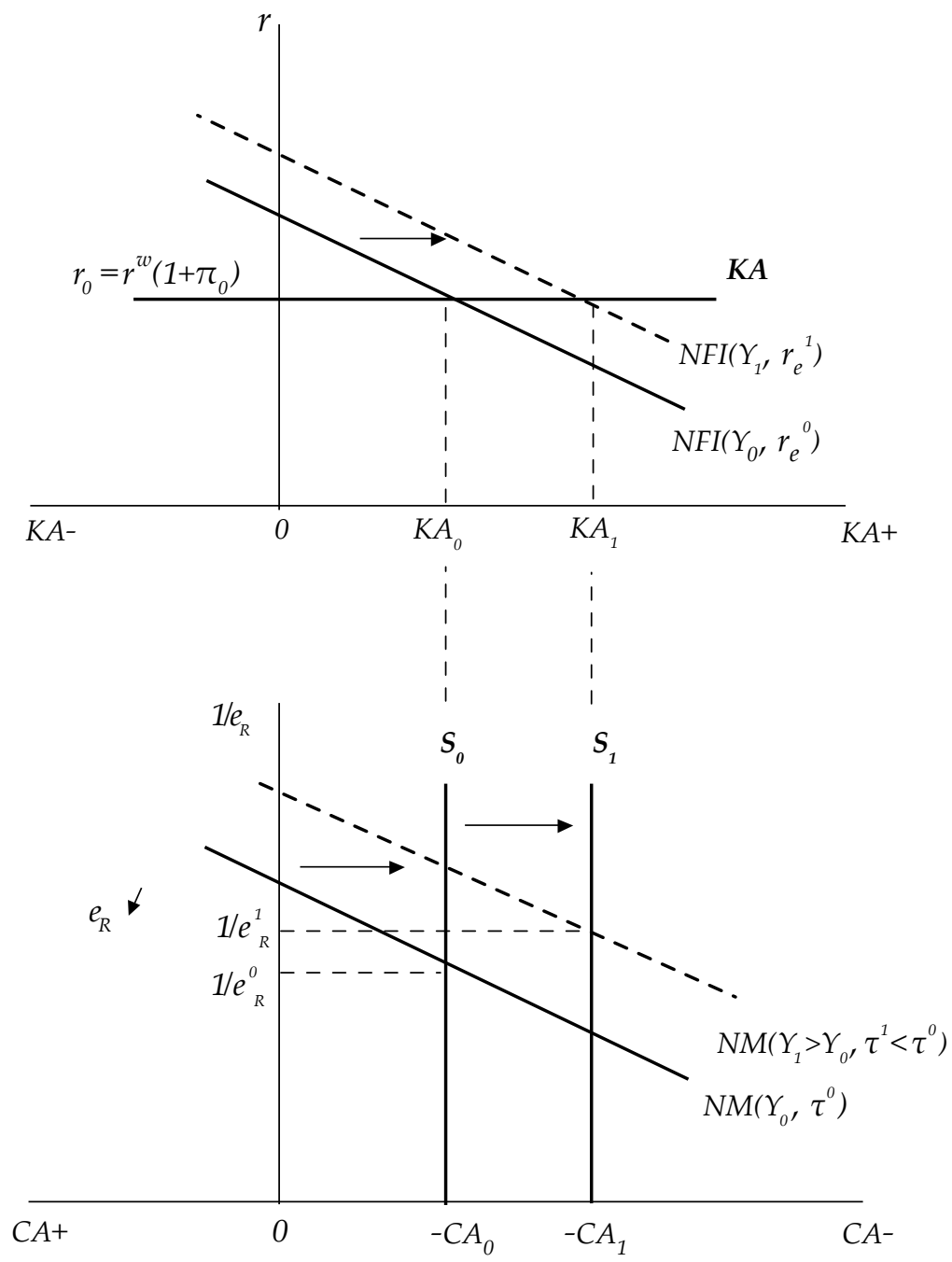